\title{
VALORI COMUNE ALE ORGANIZAT,IEI MILITARE ŞI ALE DOMENIULUI EDUCAȚIE FIZICĂ ȘI SPORT
}

\author{
COMMON VALUES OF THE MILITARY ORGANIZATION \\ AND OF THE FIELD OF PHYSICAL EDUCATION AND SPORT
}

\author{
Lt.col.instr.sup.drd. Marius Constantin ISTRATE* \\ Col. (r) prof.univ.dr. Ion BĂLĂCEANU**
}

\begin{abstract}
Organizația militară, datorită rolului său fundamental în apărarea, menținerea suveranităţii și securităţii oricărui stat de pe mapamond, a cunoscut un proces evolutiv firesc. În cadrul acestui proces, omul deține rolul principal. Astfel, transformarea continuă la care a fost și este supusă organizația militară, fiind permanent condiționată de amenințările și de provocările în continuă schimbare, s-a realizat concomitent cu evoluţia omului, sub impactul tuturor descoperirilor și tehnologiilor dezvoltate și implementate de către acesta. În acest articol, vom analiza două domenii importante ale activităţii umane, organizația militară și cea sportivă, concentrând efortul pentru depistarea de valori comune celor două domenii și pentru generarea de răspunsuri pertinente la întrebarea: O echipă sportivă este echivalentă unei structuri militare?

The military organization, due to its fundamental role in defending and maintaining the sovereignty and security of any state in the world, has undergone a natural evolutionary process. In this process man plays the main role. Thus, the continuous transformation to which the military organization was and is still subjected to, being permanently conditioned by the constantly changing threats and challenges, was achieved simultaneously with human evolution, under the impact of all discoveries and technologies developed and implemented by it. In this article, we will analyze two important areas of human activity, military organization and sports, focusing on finding common values for the two areas and generating relevant answers to the question: Is a sports team equivalent to a military structure?
\end{abstract}

Cuvinte-cheie: organizația militară; educație fizică și sport; valori comune; conexiuni.

Keywords: military organization; physical education and sports; common values; connections.

Îndeplinirea misiunilor specifice organizaţiei militare se bazează pe un proces unitar, deosebit de complex, de instruire, în care toate elementele sale componente (de natură teoretică, tactică, tehnică, psihologică etc.) dețin roluri bine stabilite, fiind strâns legate și interdependente.

Elementul cheie care realizează conexiunea dintre toate aceste componente ale procesului de instruire militară este, bineînțeles, resursa umană. Prin urmare, concomitent cu transformările de tip structural, conceptual și metodologic la care este supusă organizația militară, accentul principal trebuie pus pe dezvoltarea resursei umane, pe găsirea unor soluții viabile pentru formarea și instruirea unor luptători valoroși, capabili de

\footnotetext{
*Universitatea Naţională de Apărare „Carol I” e-mail: mariusconstantinistrate@yahoo.com

**Universitatea Naţională de Apărare „Carol I" e-mail: balaceanuion@yahoo.com
}

orice sacrificiu, cu calități, competente, deprinderi și abilități practice necesare pentru a face față provocărilor de orice natură. Astfel, pentru îndeplinirea misiunii principale a organizației militare, „obținerea supremației și a victoriei în orice tip de confruntare armată"', considerăm că modernizarea și reformarea sistemului actual de educație fizică militară reprezintă una dintre soluțiile cele mai viabile și, totodată, ușor abordabile, ținând cont de faptul că educația fizică militară reprezintă „o componentă fundamentală a procesului de instrucție/învăţământ care valorifică sistematic ansamblul formelor de activitate colectivă sau individuală, ce se desfășoară în vederea formării, dezvoltării și menținerii capacităţii motrice, contribuind la îmbunătățirea stării de sănătate fizică și psihică a personalului armatei"’2, iar prin practicarea activităţilor fizice, omul se dezvoltă pe toate planurile, beneficiile acestora fiind unanim recunoscute atât de specialiștii în domeniu, cât și de lumea medicală. 


\section{Aspecte istorice ale conexiunii educației militare cu educația fizică și sportul}

Între organizația militară și educația fizică există dintotdeauna o legătură indisolubilă, cele două fiind instituții ale căror activități s-au întrepătruns permanent și chiar s-au confundat. Interferențele dintre organizația militară și domeniul educație fizică și sport, domeniu care include o gamă variată de activităţi sistematice de pregătire fizică, educație fizică și de competiții sportive, coboară în negura timpului până în perioada antică, în mod special în civilizația greacă, care era foarte preocupată de cultivarea frumuseții fizice și morale, a virtuților, grecii fiind adepți ai întrecerilor, ai cultului eroilor cetăților, eroi - câștigători ai Jocurilor Olimpice sau învingători pe câmpurile de bătălie ${ }^{3}$.

Conexiunea existentă între organizația militară și domeniul educației fizice reiese și din faptul că, în vremurile trecute, perioade de timp în care toate diferendele se rezolvau prin forță, prin conflicte armate, forța și rezistența fizică a luptătorilor erau determinante, înclinând balanţa victoriei finale de o parte sau de cealaltă. Prin urmare, comandanții militari au fost permanent interesaţi de antrenarea și condiția fizică a soldaților pe care îi aveau la dispoziție. Mai mult, cu câteva excepții, regii, împărații sau conducătorii diferitelor cetăți, entități statale sau chiar imperii din acele vremuri trebuiau să facă dovada că sunt puternici, că stăpânesc desăvârșit tehnica armelor, atitudinea și calitățile lor fiind factorul psihologic prin care determinau armatele să îi urmeze, uneori, chiar până la sacrificiul suprem. Acestea dovedesc că, de-a lungul istoriei, pe întreg parcursul devenirii sale, educația fizică a avut o determinare de ordin militar și politic, și astfel s-a evidențiat printr-un puternic caracter militar, integrându-se perfect în cadrul procesului de pregătire necesar instruirii și ducerii războiului.

Treptat, odată cu dezvoltarea societăţii moderne, la sfârșitul secolului al XVIII-lea și începutul secolului al XIX-lea, s-a făcut trecerea de la exercițiile fizice desfășurate empiric, nu foarte organizat, la sisteme complete de educație fizică, organizate pe baze științifice și pe concepții pedagogice generale, adaptate realităților politice și caracteristicilor sociale alestatelor din acea perioadă. Practic, prin înființarea unor instituții specializate în acest domeniu (Societatea Gimnastica, în 1799, respectiv Institutul pentru gimnastică militară, în 1804, în Copenhaga - Danemarca, Institutul
Regal de Gimnastică din Stockholm - Suedia, în 1813, Institutul Durdan, din Paris, în 1817, Clubul Atletic de Amatori din Londra - Anglia, în 1866), s-a semnat actul de naștere a sistemului modern de educație fizică. În majoritate, cei care, prin efortul și strădania lor, au reformat această activitate proveneau din cadrul organizației militare sau aveau o legătură strânsă cu aceasta (colonelul spaniol Don Francesco Amoros y Ondeano, în Franța, Friedrich Ludwig Jahn, în Germania - participant la războiul de eliberare ca voluntar în armata prusacă -, Franciscus Nachtegall, în Danemarca profesor și director al Institutului pentru gimnastica militară etc.). Acești iluștri promotori ai educației fizice au înțeles pe deplin rolul fundamental pe care o bună pregătire fizică îl are în dezvoltarea societăților și națiunilor în ansamblul lor, reușind astfel introducerea acestei discipline în programele de învățământ și contribuind la educarea tinerei generații, resursa umană care reprezintă viitorul oricărei națiuni.

Și în țara noastră educația fizică s-a dezvoltat tot cu aportul unor militari de carieră: generalul doctor Carol Davila, ofițerii Justin Mărginean și Virgil I. Bădulescu, sprijiniți de Alteța Sa Regală Principele Carol și de comandanţii militari ai acelor vremuri (generalul Grigore Crăiniceanu - ministru de război -, generalul Constantin Herjeu - șef al Marelui Stat Major etc.). Dintre toți cei care au militat și au participat direct la dezvoltarea acestei activităţi, întemeietorul sistemului modern de educație fizică din țara noastră, unanim recunoscut, este generalul Virgil I. Bădulescu. Acesta, pe lângă faptele de vitejie pe care le-a înfăptuit, alături de vânătorii de munte, în Primul Război Mondial (a înființat și a comandat primul batalion de vânători de munte din Armata României, în fruntea căruia a obținut victorii răsunătoare în luptele de la Coșna și Cireșoaia ${ }^{4}$ ), și-a dedicat întreaga carieră și viață educaţiei fizice.

Aportul pe care 1-a avut la dezvoltarea acestei activități este impresionant: a adus și a implementat în sistemul de învățământ din țara noastră unul dintre cele mai complete sisteme de educație fizică la acea vreme, respectiv modelul suedez; a participat direct, a coordonat și a condus înființarea primelor organisme și instituții specializate în acest domeniu (Școala Militară de Scrimă şi Gimnastică - 1913, Oficiul Național de Educație Fizică - 1922, Institutul Național de 
Educație Fizică - prima instituție universitară de profil-1922, Institutul Militar de Educație Fizică - 1929); a fost iniţiatorul primului proiect pentru ceea ce avea să devină prima lege a educației fizice din România, Legea pentru educație fizică - 1923, și, ulterior, a contribuit la îmbunătăţirea acesteia, care s-a transformat, în 1929, în Legea educaţiei fizice; a contribuit efectiv la dezvoltarea bazei materiale și la construirea primelor facilități specifice acestei activităţi (primul stadion din România - stadionul ONEF, poligonul ONEF, Complexul sportiv și bazinul de înot din stațiunea Eforie etc.); a scris primele instrucțiuni, manuale și regulamente de specialitate, a editat prima revistă de educație fizică „Izvor de energie”, în anul 19215, și a avut o contribuție cu adevărat remarcabilă la dezvoltarea cercetării științifice în acest domeniu. Astfel, elocvent pentru legătura dintre cele două pasiuni ale sale, respectiv organizația militară și educaţia fizică, acesta spunea: „In toate timpurile și pretutindeni aceste două noțiuni s-au confundat și nu s-au putut separa una de alta fără a constitui un regres sau o primejdie".

În concluzie, aspectele istorice prezentate în prima parte a studiului nostru scot în evidență necesitatea și importanța activităților de educaţie fizică și sport și a educației militare, cele două domenii având conexiuni istorice, se întrepătrund și se completează reciproc, amândouă ajutând la atingerea unor scopuri educative și la obținerea unor rezultate benefice pentru ființa umană.

\section{O echipă sportivă este echivalentă unei structuri militare?}

După această perioadă de început, de căutări și de așezări, sistemul de educație fizică și-a urmat cursul firesc, în zilele noastre atingând un înalt nivel de dezvoltare, cercetarea și promovarea acestui domeniu nemaifiind apanajul exclusiv al militarilor. $\mathrm{Cu}$ toate acestea, influența datorată originii militare a educației fizice și elementele specifice acestei origini nu vor dispărea, iar legătura dintre factorul militar și sistemul de educație fizică va dăinui pentru totdeauna. $\mathrm{Cu}$ alte cuvinte, și în contextul cercetărilor noastre, între organizaţia militară și domeniul specific educației fizice și sportului, se păstrează o multitudine de asemănări şi de elemente comune, începând cu modul de organizare a activităților și ajungând la valorile comune pe care ambele le promovează.
În cadrul lecției de educație fizică, care reprezintă „unitatea organizatorică și funcțională principală a procesului instructiv-educativ", modul de organizare și de desfășurare a activităţii a păstrat caracterul tipic militar. Astfel, formațiile de lucru în linie pe trei, în linie pe un rând, in coloană câte unul etc., precum și pozițiile, mișcările de front și exercițiile de front și formație cu care se începe de obicei lecția de educaţie fizică sunt, în mare, aceleași ca în instrucția militară. Aceleași caracteristici cazone îmbracă și o parte din terminologia și comenzile uzitate de profesor sau de instructor pe timpul desfășurării orei de educație fizică.

Organizarea pe ateliere a activităţii este un alt element comun, fiecare atelier fiind coordonat de un responsabil (instructor). Acest responsabil este bine instruit înainte de începerea activității de către profesorul de educație fizică, respectiv de către comandantul de subunitate, în cazul organizației militare, pe toată perioada activităţii purtând și responsabilitatea pentru desfășurarea în condiții bune și de siguranţă a acesteia.

O similitudine există și între respectarea regulilor de angajare, în cazul acțiunilor militare, reguli prevăzute în Dreptul Internaţional Umanitar, și fairplay-ul sportiv, ambele promovând o relație cât mai corectă între combatanți: respectarea drepturilor fundamentale ale omului, cultivarea respectului pentru sine și pentru adversari, respectarea legilor, regulamentelor şi cutumelor, precum şi stabilirea unor limite clare pe timpul desfășurării acestor activităţi. Mai mult, în cadrul activităţilor sportive, regăsim și majoritatea elementelor caracteristice artei militare, tacticii militare, forme de acțiune specifice ducerii operațiilor militare, ca atacul, apărarea, contraatacul, hărțuirea, prin care militarii urmăresc îndeplinirea cu succes a misiunilor de luptă, iar sportivii, realizarea obiectivelor de performanță și a celor competiționale.

O echipă sportivă este echivalentă unei structuri militare. Astfel, alegerea unei strategii bune de către comandant (antrenor sau manager, în plan sportiv), adaptarea permanentă a acesteia, în funcție de răspunsul adversarului, precum și respectarea întocmai de către militari (jucători) a planului tactic reprezintă premise solide pentru obținerea victoriei. Mai mult, atât pe câmpul de luptă, cât și în arena sportivă, combatanţii urmăresc permanent să își domine adversarul, să ,îl culce” la pământ, să 
îl învingă. Diferența majoră este că, spre deosebire de confruntările sportive, la finalul cărora oponenții „se ridică” și „se scutură”, își strâng mâinile și se felicită reciproc, în cazul confruntărilor militare, lucrurile nu stau la fel, mulți dintre cei căzuți nemaiavând șansa să se ridice.

Activitățile specifice acestui domeniu, pe lângă finalităţile biologice, influențează pozitiv și sfera psihologică și socială, educă trăsăturile de caracter și de voință ale indivizilor (curaj, fermitate, ambiție, onestitate, emulație, perseverență), precum și calitățile sociale ale acestora (spiritul de echipă, angajamentul, solidaritatea, toleranța, camaraderia). Toate aceste calităţi și trăsături ale indivizilor potențează valorile specifice organizației militare, ca spiritul de corp și coeziunea, cresc moralul și nivelul de motivație al militarilor, elemente esențiale pentru obținerea succesului în luptă. În structurile militare în care gradul de coeziune este ridicat, militarii luptă și se coordonează mult mai bine, se instruiesc la standarde înalte, conlucrează şi se coordonează foarte bine, nu cedează psihic atât de uşor şi suportă stresul timp îndelungat ${ }^{8}$.

Rolul fundamental pe care activităţile specifice domeniului educație fizică și sport îl au în cadrul organizaţiei militare este subliniat în Concepţia de educaţie fizică şi sport în Armata României. Astfel, „educaţia fizică militară reprezintă baza de plecare a întregului proces de pregătire pentru luptă, pivotul celorlalte componente ale instruirii, ce determină randamentul militarilor în îndeplinirea misiunilor de luptă și eficiența activităților pe timp de pace"

\section{Concluzii}

De-a lungul istoriei, educația militară și educația fizică și sportul au evoluat împreună, legate indisolubil, precum două domenii care s-au întrepătruns, uneori s-au confundat, deoarece ambele concepte aveau multiple asemănări și promovau valori similare.

Pe întreg parcursul devenirii sale, educaţia fizică a avut determinări de ordin militar și politic, s-a evidențiat printr-un puternic caracter militar, integrându-se perfect în cadrul procesului de pregătire necesar instruirii, planificării și ducerii războiului.

Este unanim recunoscut faptul că domeniul educație fizică și sport reprezintă una dintre cele mai importante componente ale educaţiei permanente, cu un aport deosebit în formarea și educarea omului la toate vârstele, în creșterea, dezvoltarea personală și desăvârșirea profesională a acestuia.
Activitățile proprii domeniului educație fizică și sport contribuie la amplificarea și consolidarea valorilor proprii organizației militare, precum și la educarea și perfecționarea calităților fizice și psihice ale militarilor.

Originea militară a educației fizice și elementele specifice acestei origini nu vor dispărea, deoarece legătura dintre sistemul militar și sistemul de educație fizică va dăinui pentru totdeauna.

\section{NOTE:}

1 A. Pelmuș, Educația fizică militară - trecut, actualitate şi perspectivă, Editura Universităţii Naţionale de Apărare „Carol I”, Bucureşti, 2019, p. 5.

2 *** Regulamentul educației fizice militare, Editura Centrul Tehnic-Editorial al Armatei, București, 2013, p. 7.

3 A. Petrache, Sportul şi armata, Editura Militară, București, 2013, p. 11.

4 C.F. Nicolescu, Pagini uitate din istoria educației fizice, Editura Enciclopedică, București, 2014, p. 33.

5 P. Dungaciu, Virgil Bădulescu, fondatorul ANEFS, 120 de ani de la naşterea sa, Biblioteca Academiei Naţionale de Educație Fizică și Sport, București, 2002, pp. 6-9.

6 D. Bâsceanu, Armata și sportul, Editura Militară, București, 1997, p. 31.

7 *** Regulamentul educației fizice militare, Editura Centrul Tehnic-Editorial al Armatei, București, 2013, p. 10.

8 http://www.resboiu.ro/coeziunea-la-grup-si-spiritulde-corp/, accesat la 02.03.2021.

9 *** Concepţia de educaţie fizică şi sport în Armata României, Statul Major General, Bucureşti, 2016, p. 8.

\section{BIBLIOGRAFIE}

*** Regulamentul educației fizice militare, Editura Centrul Tehnic-Editorial al Armatei, București, 2013.

*** Concepţia de educaţie fizică şi sport în Armata României, Statul Major General, Bucureşti, 2016.

Bâsceanu D., Armata și sportul, Editura Militară, București, 1997.

Dungaciu P., Virgil Bădulescu, fondatorul ANEFS, 120 de ani de la nașterea sa, Biblioteca Academiei Naționale de Educație Fizică și Sport, București, 2002.

Nicolescu C.F., Pagini uitate din istoria educației fizice, Editura Enciclopedică, București, 2014.

Pelmuș A., Educația fizică militară - trecut, actualitate şi perspectivă, Editura Universităţii Naţionale de Apărare „Carol I”, Bucureşti, 2019.

Petrache A., Sportul şi armata, Editura Militară, București, 2013.

http://www.resboiu.ro/coeziunea-la-grup-sispiritul-de-corp/ 